\title{
Various nopaline catabolism genes located outside the Ti-plasmids in Agrobacterium tumefaciens strains
}

\author{
Hiroetsu Wabiko, ${ }^{*}$ Masako Kagaya and Hiroshi Sano \\ Laboratory of Molecular Genetics, Biotechnology Institute, Akita Prefectural College of Agriculture, 2-2, Minami, \\ Ohgata, Akita 010-04, Japan
}

(Received 3 July 1989; revised 4 September 1989; accepted 28 September 1989)

\begin{abstract}
The structure and location of nopaline catabolism (noc) genes were examined in various Agrobacterium tumefaciens strains by plasmid transfer and by Southern hybridization analysis. In a pathogenic strain, PyTS3, the noc genes were identified both on the Ti-plasmid, pTiPyTS3, and on the cryptic plasmid, pCr140. Plasmid pCr140 was transmitted to another $A$. tumefaciens strain at a higher frequency than was pTiPyTS3. Southern hybridization analysis, using Ti-plasmid-derived noc genes as a probe, indicated that the noc genes of pTiPyTS3 differed structurally from those of $\mathrm{pCr} 140$. Three non-pathogenic strains possessed plasmids that hybridized to the probe, and all showed identical patterns of hybridization after restriction enzyme cleavage. However, this pattern was different from those of pTiPyTS3 and pCr140. Only pCr140 showed partial hybridization to the probe. A nonpathogenic strain, PyON8, that grew on both nopaline and octopine, showed no hybridization of its plasmid or chromosome to the probe. Since nopaline-utilizing transconjugants were not obtained from PyON8, the noc genes in PyON8 may be chromosomally located. These results indicate that $\boldsymbol{A}$. tumefaciens contains diverse noc genes which differ in both organization and cellular localization.
\end{abstract}

\section{Introduction}

Crown gall tumours are induced on various plants upon infection by the soil bacterium Agrobacterium tumefaciens. Virulent $\boldsymbol{A}$. tumefaciens strains contain a number of plasmids of various sizes, one of which is the tumourinducing plasmid, or Ti-plasmid (Van Larebeke et al., 1974). Part of this plasmid, known as T-DNA, is integrated into plant chromosomes (Chilton et al., 1977), and expression of the genes on the T-DNA involved in phytohormone synthesis is required for initiation and maintenance of tumorous tissues (Akiyoshi et al., 1984; Thomashow et al., 1984). Except for a few instances, functions have not been ascribed to the other, as yet cryptic, plasmids in A. tumefaciens.

The tumorous tissues induced by $A$. tumefaciens produce and secrete unusual metabolites termed opines: nopaline, octopine, agropine and others (Bomhoff et al., 1976; Nester et al., 1984). The genes required for opine synthesis are found on the T-DNA, while the genes responsible for opine catabolism are located outside the T-DNA on the Ti-plasmid (Holsters et al., 1980). In most cases, the type of opine catabolism encoded in a given $\mathrm{Ti}$ plasmid is the same as that of opine synthesis. The importance of opine synthesis to plants has not yet been established, but $A$. tumefaciens uses the opines as a source of carbon and nitrogen, and thus is able to survive in association with crown gall tumours. Another function of the opines is to promote conjugal transfer of Ti-plasmids between $A$. tumefaciens strains (Klapwijk et al., 1978; Ellis et al., 1982).

Some $A$. tumefaciens strains are non-pathogenic, and still capable of utilizing opines (Merlo \& Nester, 1977). These strains also possess several plasmids, one of which carries opine catabolism genes (Hooykaas et al., 1980). Some DNA sequence homology exists between $\mathrm{Ti}$ plasmids and plasmids from non-pathogenic strains (Merlo \& Nester, 1977), but the relationship between opine catabolism genes in pathogenic and non-pathogenic strains has not been well studied.

Here we report the distribution of the nopaline catabolism (noc) genes in $A$. tumefaciens and the structural relationship among these genes.

\section{Methods}

Bacterial strains, plasmids, media and chemicals. Agrobacterium strains used in this study are listed in Table 1. A. tumefaciens strains were isolated from crown gall tissues as reported previously (Wabiko et al., 1989). The hybrid plasmid pGV0339, provided by Dr J. Schell (MaxPlanck Institute, FRG), is composed of the vector pBR322 and HindIII 
Table 1. Agrobacterium strains

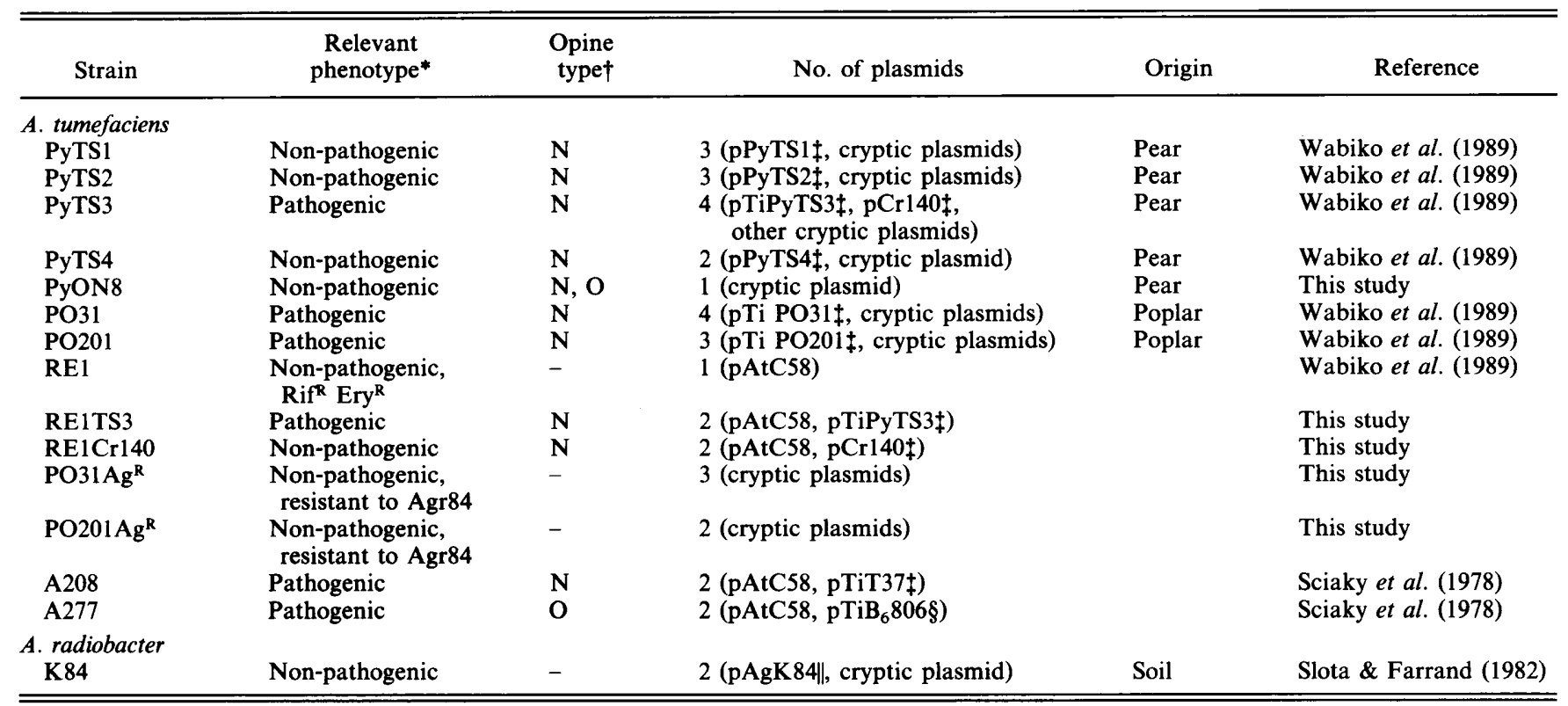

${ }^{*}$ Rif $^{\mathrm{R}}$, rifampicin resistance; Ery ${ }^{\mathrm{R}}$, erythromycin resistance.

$\dagger N$, nopaline type; $O$, octopine type.

$\ddagger$ Nopaline utilization.

\& Octopine utilization.

|| Agrocin 84 producer.

fragment $2(11 \mathrm{~kb})$ of the nopaline-type Ti-plasmid pTiC58 (Depicker et al., 1980). This $11 \mathrm{~kb}$ fragment contains nocB and nocC genes required for synthesis of the protein involved in nopaline uptake (termed $\mathrm{n} 1$ protein) and nopaline oxidase respectively (see Fig. 1 of Schardl \& Kado, 1983). The T-DNA clone pT37P1 (provided by Dr Y. Machida, Nagoya University, Japan) was derived from pTiT37 (Wabiko et al., 1989). Minimal media were AB (Chilton et al., 1974), SMNO (Lichtenstein \& Draper, 1985) and the mineral salt mixture of Petit \& Tempe (1978). Nopaline and octopine were purchased from Sigma.

Bacterial conjugation and transformation. Cells of donor strains were mixed with cells of the recipient RE1 (Table 1) as described by Lichtenstein \& Draper (1985), and transconjugants capable of utilizing nopaline were selected on SMNO plates containing $100 \mu \mathrm{g}$ rifampicin $\mathrm{ml}^{-1}, 150 \mu \mathrm{g}$ erythromycin $\mathrm{ml}^{-1}$ and $100 \mu \mathrm{g}$ nopaline $\mathrm{ml}^{-1}$ (as a nitrogen source). Transformation of RE1 by plasmid DNA was done by the freeze-thaw method (Holsters et al., 1978), and nopalineutilizing transformants were selected on SMNO plates containing $100 \mu \mathrm{g}$ nopaline $\mathrm{ml}^{-1}$ as a nitrogen source.

Selection of derivatives resistant to agrocin 84 ( Agr84). Bacterial cells were streaked close to a lawn of the Agr84-producing strain $A$. radiobacter $\mathrm{K} 84$ that had been grown at $29^{\circ} \mathrm{C}$ for $2 \mathrm{~d}$ on $\mathrm{AB}$ medium (Unger et al., 1985). Colonies surviving in the area where normal growth was inhibited were isolated and tested for Agr84 resistance in a similar manner. The selected colonies, regarded as resistant clones, were used for further analysis.

Test of opine and arginine utilization. Bacterial cells were streaked onto the mineral salt mixture supplemented with nopaline, octopine or arginine (each $10 \mathrm{~mm}$ ) as a carbon source, and $1.8 \%(\mathrm{w} / \mathrm{v})$ Noble agar (Difco) which had been washed with deionized water prior to use.
These media contained $\left(\mathrm{NH}_{4}\right)_{2} \mathrm{SO}_{4}\left(2 \mathrm{~g} \mathrm{l}^{-1}\right)$ as a nitrogen source. The bacteria were incubated at $29^{\circ} \mathrm{C}$ for $4-7 \mathrm{~d}$.

Plasmid preparation and hybridization. To identify the number of plasmids, the rapid alkali/SDS lysis method (Kado \& Liu, 1981) was employed. To isolate plasmid DNA, total DNA was briefly sheared, denatured with alkali, and the plasmid DNA was purified by $\mathrm{CsCl} /$ ethidium bromide density-gradient centrifugation as described by Currier \& Nester (1976). Upon shearing, intact molecules of the large cryptic plasmid pAtC58 represented less than $1 \%$ of the plasmid preparation (determined by visual inspection of ethidium-bromidestained purified DNA on agarose gel); this did not interfere with subsequent restriction enzyme digestion analysis or hybridization analysis under our experimental conditions.

To purify chromosomal DNA, the same procedure was followed except that the shearing and alkali denaturation steps were omitted. The purified DNA was digested with appropriate restriction enzymes and subjected to Southern hybridization analysis (Maniatis et al., 1982). Hybridization was performed at $42^{\circ} \mathrm{C}$ for $15 \mathrm{~h}$ in a solution consisting of $50 \mathrm{~mm}$-Tris/ $\mathrm{HCl} \mathrm{pH} 7.5,1 \mathrm{~mm}$-EDTA, $0.5 \% \mathrm{SDS}, 100 \mu \mathrm{g}$ sonicated calf thymus DNA ml ${ }^{-1}, 20 \mu \mathrm{g}$ E. coli tRNA ml ${ }^{-1}, 1 \times$ Denhardt's solution $(0.02 \%$ bovine serum albumin, $0.02 \%$ Ficoll, $0.02 \%$ polyvinylpyrrolidone), $3 \times \mathrm{SSC}(1 \times \mathrm{SSC}$ is $0.15 \mathrm{M}-\mathrm{NaCl}$, $0.015 \mathrm{M}$-sodium citrate), $50 \%(\mathrm{v} / \mathrm{v})$ formamide, $10 \%(\mathrm{w} / \mathrm{v})$ dextran sulphate, and radioactive probe labelled by nick-translation $\left(1-5 \times 10^{5}\right.$ c.p.m. $\mathrm{ml}^{-1} ; 1-4 \times 10^{7}$ c.p.m. $\left.\mu \mathrm{g}^{-1}\right)$. Washing was carried out at high stringency in $0.1 \times \mathrm{SSC}, 0.1 \% \mathrm{SDS}$ at $65^{\circ} \mathrm{C}$, or at low stringency in $2 \times$ SSC, $0.1 \%$ SDS at $65^{\circ} \mathrm{C}$. The low-stringency washing conditions allowed about $24 \%$ more base-pair mismatch than the high-stringency conditions. Colony hybridization was performed with Gene Screen Plus filters (New England Nuclear) according to the manufacturer's instructions. 
Tumorigenicity assay. Intact tomato stems were inoculated with $10^{4}-10^{5}$ cells of $A$. tumefaciens using needles as described previously (Wabiko et al., 1989).

\section{Results}

\section{noc genes on a cryptic plasmid}

A nopaline-type pathogenic strain, PyTS3, possessed four plasmids ranging in size from 140 to $350 \mathrm{~kb}$. Of these, a $260 \mathrm{~kb}$ plasmid was established as the Ti-plasmid (pTiPyTS3) since it hybridized to a known T-DNA clone (Wabiko et al., 1989). In order to obtain a strain carrying only pTiPyTS3, a mating experiment was performed using PyTS3 as donor and RE1 (Rif ${ }^{R}$ Ery $\left.{ }^{R}\right)$ as recipient, and RE1 transconjugants capable of growing on nopaline $\left(\mathrm{noc}^{+}\right)$were selected. The frequency of transfer was $1-10 \times 10^{-6}$ per recipient RE1; similar frequencies were observed when the donor was substituted by other pathogenic or non-pathogenic strains (data not shown). Preliminary screening showed that several noc $^{+}$transconjugants unexpectedly contained the $140 \mathrm{~kb}$ cryptic plasmid (pCr140) but did not contain pTiPyTS 3 and did not induce tumours on tomato. We examined 459 noc $^{+}$transconjugants by colony hybridization using two different probes: a part of T-DNA (T37P1), which hybridizes only to pTiPyTS3, and $\mathrm{pCr} 140$, which hybridizes only to pCr140. Of the 459 noc $^{+}$transconjugants, 452 hybridized to $\mathrm{pCr} 140$, while only seven hybridized to T-DNA; the latter class possessed only the $260 \mathrm{~kb}$ pTiPyTS3. Thus pCr140 was transferred from PyTS3 to REl about 65 times (452/7) more efficiently than pTiPyTS 3 in the presence of nopaline. These results indicated that in strain PyTS3, the noc genes resided both on the non-pathogenic cryptic plasmid, pCr140, and on the Ti-plasmid, pTiPyTS3.

In order to determine whether the occurrence of noc genes on cryptic plasmids is a general phenomenon, we examined two other pathogenic strains, PO31 and PO201, from poplar galls, which contained four and three plasmids, respectively. The ${ } \mathrm{cc}^{+}$transconjugants obtained from crosses between either of these strains and RE1 possessed only $200 \mathrm{~kb}$ Ti-plasmids. Furthermore, as most nopaline-type Ti-plasmids confer sensitivity to the antibiotic Agr84, two Agr84-resistant derivatives, $\mathrm{PO} 31 \mathrm{Ag}^{\mathrm{R}}$ and $\mathrm{PO} 201 \mathrm{Ag}^{\mathrm{R}}$ (Table 1), were isolated as a result of spontaneous curing of the Ti-plasmids from the sensitive parents PO31 and PO201 respectively. These isolates had lost only the Ti-plasmids and had also lost the capacity to grow on nopaline, indicating that in the case of PO31 and PO201, the noc genes resided exclusively on the Ti-plasmids. These results suggested that the cryptic plasmid encoding nopaline utilization existed specifically in PyTS3.
In strains containing nopaline-type Ti-plasmids, nopaline is cleaved to give arginine, and subsequent arginine catabolism is induced by nopaline (Ellis \& Kerr, 1979). To see whether similar mechanisms exist in strains containing $\mathrm{pCr} 140$, the transconjugants RE1Cr140 (pCr140) and RE1TS3(pTiPyTS3), and one typical nopaline-type strain, A208(pTiT37), were examined for arginine utilization. As shown in Fig. $1(a-c)$, none of these strains grew on the medium containing only $10 \mathrm{mM}-$ arginine, but all grew when the medium was also supplemented with $0.1 \mathrm{mM}$-nopaline. This result indicated that arginine utilization was also induced by nopaline in the cryptic plasmid, $\mathrm{pCr} 140$, and suggested that the regulation of noc gene expression in $\mathrm{pCrl} 40$ is similar to that in Ti-plasmids.

\section{Hybridization analysis of noc genes on $\mathrm{pCr} 140$}

The structure and location of the noc genes of $\mathrm{pCr} 140$ and pTiPyTS3 were examined by Southern hybridization analysis. Plasmid DNA was digested with BamHI and HindIII, and the restriction patterns were analysed by hybridization to a probe consisting of a part of the noc operon (containing the $n o c B$ and nocC genes) from the well-known Ti-plasmid pTiC58. High- and low-stringency washing conditions were employed so as to determine the extent of DNA sequence homology between pCr140 and pTiPyTS3.

Under high-stringency conditions, $1.7 \mathrm{~kb} \mathrm{BamHI}$ and $11 \mathrm{~kb}$ HindIII fragments of $\mathrm{pCr} 140$ hybridized with the probe (Fig. 2b). Under low-stringency conditions, however, additional $B a m \mathrm{HI}$ fragments of 3.8 and $1.3 \mathrm{~kb}$ became visible (Fig. $2 c$ ), indicating that these fragments are also part of the noc genes, but with low homology to the probe. In addition, the $1.7 \mathrm{~kb} \mathrm{BamHI}$ and the $11 \mathrm{~kb}$ HindIII fragments showed stronger hybridization intensities under low-stringency conditions (Fig. 2c), suggesting that these fragments are also only partially homologous to the probe. The total sum, $6.8 \mathrm{~kb}$ $(3.8+1.7+1.3 \mathrm{~kb})$, of the hybridized BamHI fragments was less than that of the probe $(11 \mathrm{~kb})$, suggesting that some regions of the $\mathrm{pCr} 140$ noc genes contained unique DNA base sequences that were not homologous to the probe. In contrast to the results with $\mathrm{pCr} 140,11 \mathrm{~kb}$ and $10 \mathrm{~kb}$ BamHI and $11 \mathrm{~kb}$ HindIII fragments of pTiPyTS3 showed strong hybridization to the probe under both high- and low-stringency conditions (Fig. 2b, c). Similarly, another well-studied Ti-plasmid, pTiT37, also showed strong hybridization signals to the probe under both washing conditions (Fig. 3). These results indicate that the noc genes of the cryptic plasmid pCrl40 differ at least partly from those of Ti-plasmids, while the noc genes of the Ti-plasmids from different origins closely resemble each other. 
(a) 10 mM-arginine

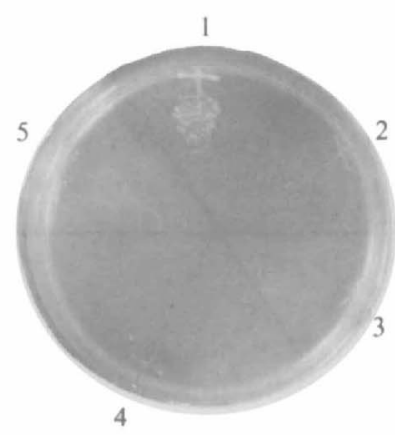

(b) 10 mM-arginine

$+0 \cdot 1$ mm-nopaline

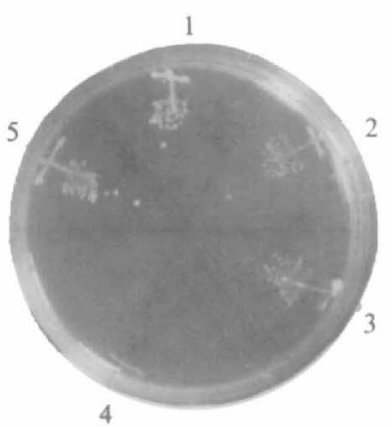

(c) $0.1 \mathrm{~mm}$-nopaline

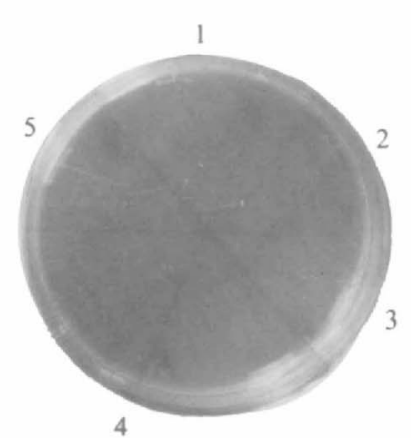

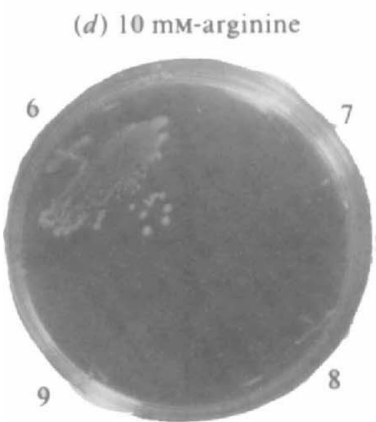
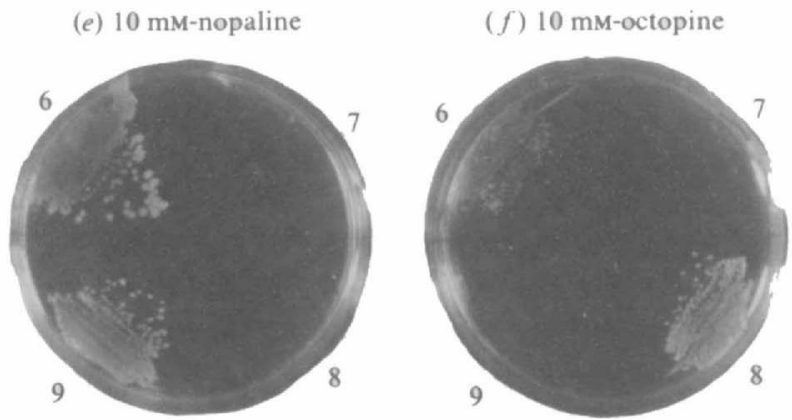

(g) Mineral salt mixture alone

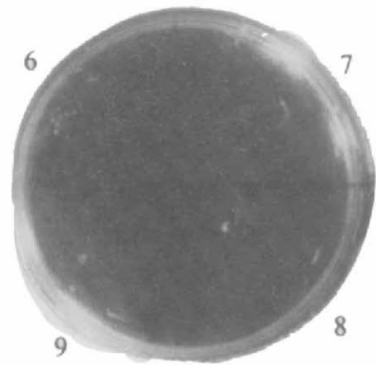

Fig. 1. Growth of $\boldsymbol{A}$. tumefaciens strains with arginine, nopaline or octopine as sole carbon source. The culture medium contained the mineral salt mixture (see Methods) supplemented with the compounds indicated in the figure. Bacterial strains are: PyTS3 (1), REICr140 (2), RE1TS3 (3), RE1 (4, 7), A208 (5, 9), PyON8 (6) and A277 (8). The bacteria were incubated for $5 \mathrm{~d}$ at $29^{\circ} \mathrm{C}$.

noc genes in non-pathogenic strains

Previously, we isolated three non-pathogenic (to tomato, petunia, poplar, kalanchöe, apple and grape), nopalinetype $A$. tumefaciens strains from crown gall tissues of pear that occurred in Ten-no, Japan (Wabiko et al., 1989). These strains contained either two (in PyTS4) or three (in PyTS1 and PyTS2) plasmids ranging from 140 to $350 \mathrm{~kb}$ in size, and the distribution of the plasmids was strainspecific. The noc genes were located on a $200 \mathrm{~kb}$ plasmid in all three strains, as recognized by hybridization to the noc probe, and by isolation of $n o c^{+}$transconjugants which had acquired only the $200 \mathrm{~kb}$ plasmids, pPyTS1, pPyTS2 and pPyTS4 (Table 1). The noc gene probe hybridized to 7.4, 4.2 and $0.64 \mathrm{~kb}$ HindIII fragments of plasmid DNA from these strains, under both high- and low-stringency conditions (Fig. 3, lanes 6-8, and data not shown). The hybridization pattern was identical among these three strains, but was different from those of pCr140 and Ti-plasmids (Fig. 2, Fig. 3).
Possibly chromosomally located noc genes

We have isolated an anomalous strain, PyON8, from crown gall tissue of pear in Ohgata, Japan. This strain, containing only one $50 \mathrm{~kb}$ plasmid, did not induce tumours on tomato, petunia, poplar, kalanchöe, apple or grape, and utilized not only nopaline but also octopine and arginine as carbon sources (Fig. $1 d-g$ ). Growth on nopaline and arginine was more pronounced than that on octopine. In order to determine whether the noc genes were located on the $50 \mathrm{~kb}$ plasmid, we attempted to transfer this plasmid into RE1 and then to screen for the acquisition of the $\mathrm{Noc}^{+}$phenotype. However, neither mating between PyON8 and RE1, nor direct transformation of REl with the $50 \mathrm{~kb}$ plasmid, produced any $\mathrm{Noc}^{+}$ strains. No hybridization of the noc probe either to the $50 \mathrm{~kb}$ plasmid or to chromosomal DNA was detected, even under low-stringency conditions and with prolonged exposure of X-ray film to the nitrocellulose filter (Fig. 3, lanes 5 and 9). These results indicate that PyON8 


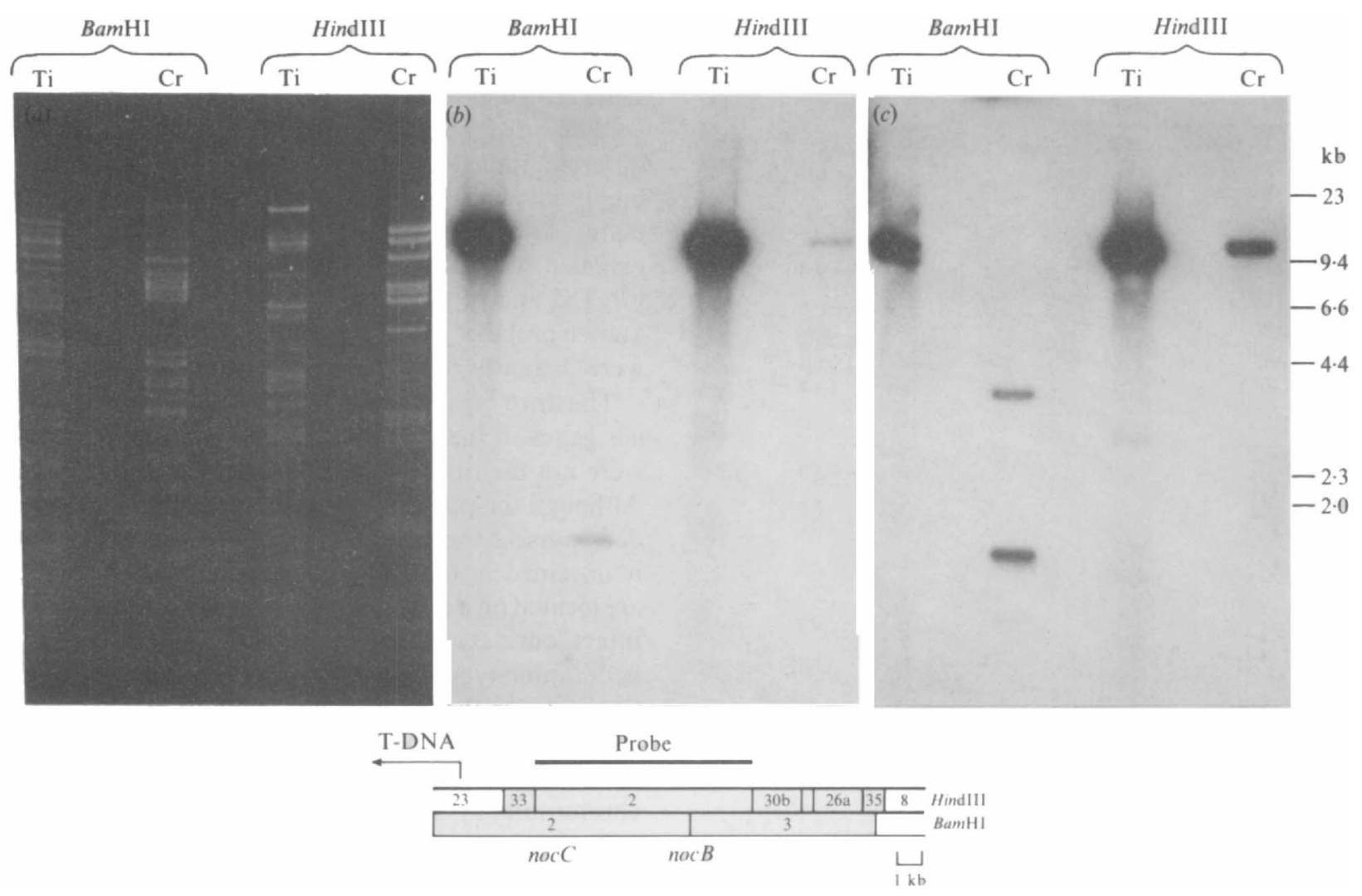

Fig. 2. Southern hybridization analysis of plasmids pTiPyTS3 and pCr140. Plasmids pCr140 and pTiPyTS3 were purified from REICrl 40 and REITS3 respectively, and then $1 \mu \mathrm{g}$ DNA of pCr140 or $1.6 \mu \mathrm{g}$ DNA of pTiPyTS3 was digested with BamHI or HindIII. The DNA fragments were separated by $0.8 \%$ agarose gel electrophoresis, and stained with ethidium bromide $\left(1 \mu \mathrm{g} \mathrm{ml}^{-1}\right)(a)$. The fragments were then transferred to nitrocellulose filters and subjected to hybridization with a radioactively labelled $11 \mathrm{~kb}$ HindIII fragment of pGV0339 (1.5 $\times 10^{6}$ c.p.m. per filter; specific activity $1.3 \times 10^{7}$ c.p.m. $\left.\mu \mathrm{g}^{-1}\right)$. The filters were washed either under highstringency $(b)$ or low-stringency $(c)$ conditions, and were then exposed to X-ray film for $24 \mathrm{~h}$ at $-80^{\circ} \mathrm{C}$. $\mathrm{Ti}$ and $\mathrm{Cr}$ refer to plasmids pTiPyTS3 and pCr140 respectively. The molecular sizes indicated on the right were determined from HindIII digests of phage $\lambda$ DNA. Part of the restriction map of pTiC58, the fragment numbers (Depicker et al., 1980; Holsters et al., 1980), and the locations of T-DNA, noc genes and the probe used in this study, are also shown.

possesses structurally unique noc genes, and that these genes reside either on a non-conjugative plasmid, or possibly on the chromosome.

\section{Discussion}

This paper describes three different types of $n o c^{+} \boldsymbol{A}$. tumefaciens strains: (1) one strain (PyTS3) contained noc genes at two loci, one on the Ti-plasmid and the other on the non-Ti cryptic plasmid; (2) three strains (PyTS1, PyTS2, PyTS4) contained noc genes only on non- $\mathrm{Ti}$ plasmids; (3) one strain (PyON8) possibly contained noc genes either on a non-conjugative plasmid or on the chromosome. Structural similarities and differences of these genes were demonstrated. The nopaline-type Tiplasmid, pTiPyTS3, and the non-Ti cryptic plasmid, pCr140, existed as separate replicons in strain PyTS3.
This is consistent with a previous report that some nonpathogenic $A$. tumefaciens strains possess plasmids that carry genes for nopaline or octopine utilization, and that these plasmids are compatible with Ti-plasmids coding for nopaline or octopine utilization (Hooykaas et al., 1980).

It was reported by Petit et al. (1983) that a few pathogenic $A$. rhizogenes strains (closely related to $A$. tumefaciens) contained not only an agropine-utilizing $\mathrm{Ri}$ (root-inducing) plasmid but also another plasmid required for catabolism of other opines - mannopine, mannopinic acid and agropinic acid - in a single cell. Together with these results, our findings establish that the opine catabolism can exist independently of pathogenicity in Agrobacterium strains.

Conjugation experiments showed that $\mathrm{pCr} 140$ was preferentially transferred to another strain over the $\mathrm{Ti}$ plasmid pTiPyTS3. This result implies that, in nature, 


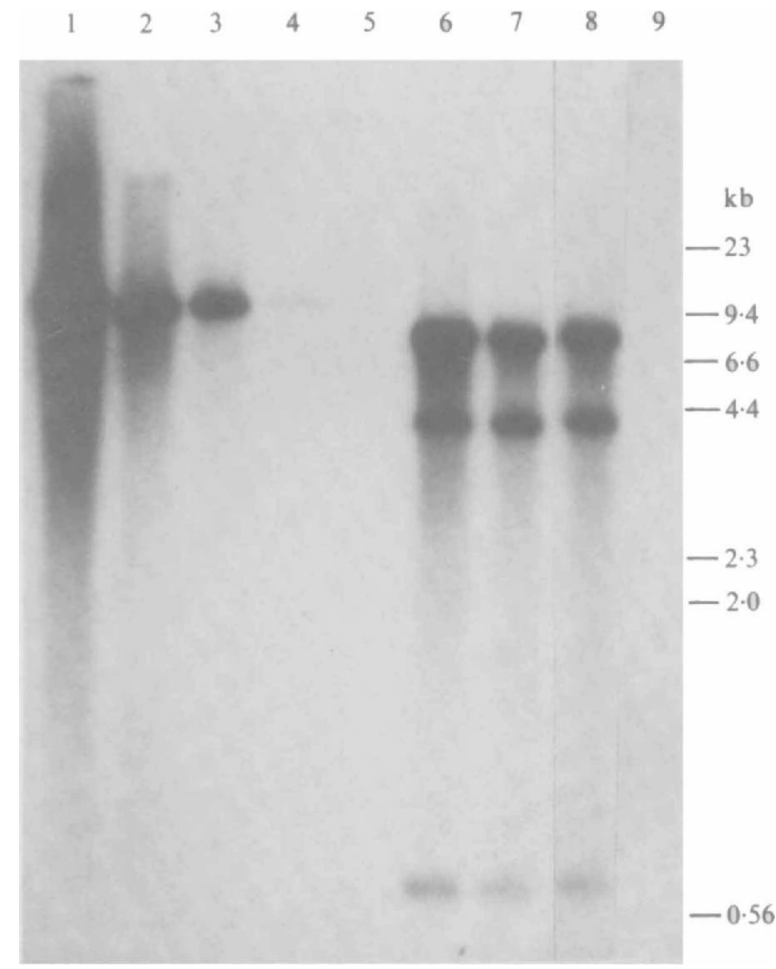

Fig. 3. Hybridization analysis of plasmids and chromosomal DNA. Plasmids and chromosomal DNA were prepared from the strains indicated, and were digested with HindIII. Lane 1, a $0.05 \mu \mathrm{g}$ sample of the $11 \mathrm{~kb} H$ indIII fragment of pGV0339; lane 2, 0.5 $\mu \mathrm{g}$ plasmid DNA from A208; lane 3, 0.8 $\mathrm{g}$ plasmid DNA from RE1TS3; lane 4, 0.5 $\mu \mathrm{g}$ plasmid DNA from REICr140; lane 5, $0.5 \mu \mathrm{g}$ plasmid DNA from PyON8; lane 6, $0.5 \mu \mathrm{g}$ plasmid DNA from PyTS1; lane $7,0.5 \mu \mathrm{g}$ plasmid DNA from PyTS2; lane 8, 0.5 $\mu \mathrm{g}$ plasmid DNA from PyTS4; lane 9, $3 \mu \mathrm{g}$ chromosomal DNA from PyON8. The probe was the same as described in the legend to Fig. 2. Radioactivities of the probe were $1.5 \times 10^{6}$ c.p.m. per filter for lanes $1-8$, and $2 \times 10^{7}$ c.p.m. for lane 9 . After hybridization, the sheets were washed under low-stringency conditions. Films were exposed at $-80^{\circ} \mathrm{C}$ for $24 \mathrm{~h}$ (lanes $1-4,6-8$ ) or for $7 \mathrm{~d}$ (lanes 5 and 9 ).

pCr140 would spread to other strains more efficiently than pTiPyTS3, particularly in tumorous plant tissues, where nopaline promotes conjugal transfer. This efficient transfer system would also help to generate nonpathogenic $A$. tumefaciens strains which would be able to survive in crown galls.

The noc genes on the plasmids, pPyTS1, pPyTS2, and pPyTS4, from three avirulent strains hybridized strongly to the noc probe. Their hybridization patterns after restriction enzyme digestion were indistinguishable, suggesting that the noc genes of these three plasmids had the same origin. However, the patterns were quite distinct from those of the noc genes borne by the $\mathrm{Ti}$ plasmid and cryptic plasmid pCr140. Thus pCr140 was apparently not the result of a transfer of one of the three avirulent, nopaline-type plasmids to the virulent strain PyTS3, even though these strains originated from the same crown gall tumour. The restriction patterns of the noc genes from pCr140, pTiPyTS3 and pPyTS1 were all different, indicating that the structure of these genes was highly diverse. However, the hybridization analyses under low- and high-stringency washing conditions revealed that the noc genes of pTiPyTS3, pPyTS1, pPyTS2 and pPyTS4 were all closely related to the wellknown probe of $\mathrm{pTiC} 58$ and that the noc genes of $\mathrm{pCr} 140$ were distantly related to the same probe.

The third type of strain, PyON8, was proposed to have noc genes in the bacterial chromosome, since noc genes were not identified on the $50 \mathrm{~kb}$ plasmid in this strain. Although the possibility remains that the $50 \mathrm{~kb}$ plasmid does possess these genes but that it could not be stably maintained in the RE1 recipient, or that the noc genes are located on a large plasmid which could not be isolated intact, our data are consistent with the observation that, in octopine-type strains, the genes for octopine degradation reside in the chromosome in addition to the plasmids (Montoya et al., 1978). To our knowledge, there is no previous report suggesting that the noc genes are chromosomally located.

The multiple locations and structural diversity of the noc genes in the various $A$. tumefaciens isolates raise several questions. First, were noc genes from both pTiPyTS3 and pCr140 expressed in strain PyTS3, and if so, is there a dosage effect upon nopaline catabolism? The similar growth rate of strains PyTS3, RE1Cr140 and REITS3 on nopaline may be explained if we assume that the rate of nopaline degradation was also similar in these strains. Second, is there any similarity among the metabolic pathways encoded by these noc genes? In the case of pCr140 and pTiPyTS3, induction of catabolism of nopaline and arginine (a cleavage product of nopaline) appears to be under identical regulation. In the case of PyON8, however, a unique catabolic pathway may exist since its noc genes did not show any homology with the known noc genes. Third, how did diverse noc genes originate? Cointegration of nopaline- and octopine-type Ti-plasmids does occur in A. tumefaciens (Hooykaas et $a l ., 1980$ ), and an agropine-type Ri-plasmid and a nonpathogenic mannopine type-plasmid form a cointegrate in $A$. rhizogenes (Petit et al., 1983). An insertion sequence (IS66) has been discovered in several locations both on plasmids and on the chromosome of A. tumefaciens (Machida et al., 1984). Such genetic rearrangements might account for different locations of the noc genes. Further, different structures of the noc genes may reflect the divergence of these genes during the evolution of Agrobacterium. The isolation and characterization of the noc operons from the strains described in this paper may well answer these questions. 
We thank Dr J. Schell for providing the recombinant plasmid pGV0339, Dr S. Youssefian for editing the text, and Ms Kouko Futada for typing the manuscript. This work was supported partly by a Grantin-Aid for Special Project Research (63616513) from the Ministry of Education, Japan.

\section{References}

Akiyoshi, D. E., Klee, H., Amasino, R. M., Nester, E. W. \& GoRDON, M. P. (1984). T-DNA of Agrobacterium tumefaciens encodes an enzyme of cytokinin biosynthesis. Proceedings of the National Academy of Sciences of the United States of America 81, 5994-5998.

BoMHOFF, G., KLAPWiJK, P. M., Kester, H. C. M. \& SCHILPEROORT, R. A. (1976). Octopine and nopaline synthesis and breakdown genetically controlled by a plasmid of Agrobacterium tumefaciens. Molecular and General Genetics 145, 177-181.

Chilton, M.-D., Currier, T. C., Farrand, S. L., Bendich, A. J., Gordon, M. P. \& Nester, E. W. (1974). Agrobacterium tumefaciens DNA and PS8 bacteriophage DNA not detected in crown gall tumors. Proceedings of the National Academy of Sciences of the United States of America 71, 3672-3676.

Chilton, M.-D., Drummond, M. H., Sciaky, D., Montoya, A. L., GoRdon, M. P. \& NesTer, E. W. (1977). Stable incorporation of plasmid DNA into higher plant cells. Cell 11, 263-271.

CURRIER, T. C. \& NeSTER, E. W. (1976). Isolation of covalently closed circular DNA of high molecular weight from bacteria. Analytical Biochemistry 76, 431-441.

Depicker, A., DE WiLde, M., De Vos, G., De Vos, R., VAn Montagu, M. \& SCHELL, J. (1980). Molecular cloning of overlapping segments of the nopaline Ti-plasmid pTiC58 as a means to restriction endonuclease mapping. Plasmid 3, 193-211.

ELLIS, J. G. \& KERR, A. (1979). Arginine catabolism : a new function of both octopine and nopaline Ti-plasmids of Agrobacterium. Molecular and General Genetics 173, 263-269.

Ellis, J. G., KerR, A., Petit, A. \& Tempe, J. (1982). Conjugal transfer of nopaline and agropine $\mathrm{Ti}$ plasmids - the role of agrocinopines. Molecular and General Genetics 186, 269-274.

Holsters, M., de Waele, D., Depicker, A., Messens, E., van MONTAGU, M. \& SCHELl, J. (1978). Transfection and transformation of Agrobacterium tumefaciens. Molecular and General Genetics 163, 181-187.

Holsters, M., Silva, B., van Vliet, F., Genetello, C., De Block, M., Dhaese, P., Depicker, A., InZe, D., Engler, G., Villaroel, R., van Montagu, M. \& Schell, J. (1980). The functional organization of the nopaline $A$. tumefaciens plasmid pTiC58. Plasmid $3,212-230$.

Hooykaas, P. J. J., Den Dulk-Ras, H., Ooms, G. \& Schilperoort, R. A. (1980). Interactions between octopine and nopaline plasmids in Agrobacterium tumefaciens. Journal of Bacteriology 143, 1295-1306.

KADO, C. I. \& LiU, S.-T. (1981). Rapid procedure for detection and isolation of large and small plasmids. Journal of Bacteriology 145, 1365-1373.
KlaPWiJK, P. M., SCheulderman, T. \& SChilperoort, R. A. (1978). Coordinated regulation of octopine degradation and conjugative transfer of Ti plasmids in Agrobacterium tumefaciens: evidence for a common regulatory gene and separate operons. Journal of Bacteriology 136, 775-785.

LiCHTENSTEIN, C. \& DRAPER, J. (1985). Genetic engineering of plants. In DNA Cloning, vol. 2, pp. 67-119. Edited by D. M. Glover. Washington, DC: IRL Press.

Machida, Y., Sakural, M., Kiyokawa, S., Ubasawa, A., Suzuki, Y. \& IKEDA, J..(1984). Nucleotide sequence of the insertion sequence found in the T-DNA region of mutant Ti plasmid pTiA66 and distribution of its homologues in octopine Ti plasmid. Proceedings of the National Academy of Sciences of the United States of America 81, 7495-7499.

Maniatis, T., Fritsch, E. F. \& SAMBrook, J. (1982). Molecular Cloning: a Laboratory Manual. Cold Spring Harbor, NY: Cold Spring Harbor Laboratory.

MerLo, D. J. \& Nester, E. W. (1977). Plasmids in avirulent strains of Agrobacterium. Journal of Bacteriology 129, 76-80.

Montoya, A. L., Moore, L. W., Gordon, M. P. \& Nester, E. W. (1978). Multiple genes coding for octopine-degrading enzymes in Agrobacterium. Journal of Bacteriology 136, 909-915.

Nester, E. W., Gordon, M. P., Amasino, R. M. \& Yanofsky, M. F. (1984). Crown gall: a molecular and physiological analysis. Annual Review of Plant Physiology 35, 387-413.

Petit, A. \& TEMPE, J. (1978). Isolation of Agrobacterium Ti-plasmid regulatory mutants. Molecular and General Genetics 167, 147-155.

Petit, A., David, C., Dahl, G. A., Ellis, J. G. \& Guyon, P. (1983). Further extension of the opine concept: plasmids in Agrobacterium rhizogenes cooperate for opine degradation. Molecular and General Genetics 190, 204-214.

SCHARDL, C. L. \& KADO, C. I. (1983). A functional map of the nopaline catabolism genes on the Ti-plasmid of Agrobacterium tumefaciens C58. Molecular and General Genetics 191, 10-16.

Sciaky, D., Montoya, A. L. \& Chilton, M.-D. (1978). Fingerprints of Agrobacterium Ti plasmids. Plasmid 1, 238-253.

Slota, J. E. \& FarRand, S. K. (1982). Genetic isolation and physical characterization of pAgK84, the plasmid responsible for agrocin 84 production. Plasmid 8, 175-186.

Thomashow, L. S., ReEves, S. \& Thomashow, M. F. (1984). Crown gall oncogenesis : evidence that a T-DNA gene from the Agrobacterium Ti plasmid pTiA6 encodes an enzyme that catalyses synthesis of indoleacetic acid. Proceedings of the National Academy of Sciences of the United States of America 81, 5071-5075.

Unger, L., Ziegler, S. F., Huffman, G. A., Knauf, V. C., Peet, R., MoOre, L. W., Gordon, M. P. \& Nester, E. W. (1985). New class of limited-host-range Agrobacterium mega-tumor-inducing plasmids lacking homology to the transferred DNA of a wide-host-range, tumor-inducing plasmid. Journal of Bacteriology 164, 723-730.

van Larebeke, N., Engler, G., Holsters, M., Van den Elsacker, S., Zaenen, I., Shilperpoort, R. A. \& SChell, J. (1974). Large plasmid in Agrobacterium tumefaciens is essential for crown gallinducing ability. Nature, London 252, 169-170.

Wabiko, H., Kagaya, M., Kodama, I., Masuda, K., Kodama, Y., Yamamoto, H., Shibano, Y. \& Sano, H. (1989). Isolation and characterization of diverse nopaline type Ti plasmids of Agrobacterium tumefaciens from Japan. Archives of Microbiology 152, 119124. 